\title{
Mantaining Bahasa Angkola by its Speakers at Langgar Community in Kota Medan
}

\author{
1) Armita Novriana Rambe \\ Student of English applied Linguistic Study Program Medan \\ Medan State University, Indonesia \\ mita_nov89@yahoo.co.id
}

\author{
${ }^{2)}$ Amrin Saragih, \\ 3) Anni Holila Pulungan \\ $2 \& 3$ ) Lecturers of English Applied Linguistic Study Program \\ Medan State University, Indonesia
}

\begin{abstract}
The aims of this study was to investigate the factors of Angkolanese maintain Bahasa Angkola at Langgar Community in Kota Medan. The research was conducted by using qualitative design. The data of this study were the utterances of Angkolanese speakerss. There were 20 participants of this research. the data were collected through observation, questionnaire and interview. The result of this study revealed that: There were seven factors that affecting language maintenance proposed by Holmes (2001) in this study namely environment, language attitude, living together and see each other frequently, use of language in family domain (intra marriage and intermarriage), use of language in neighborhood domain, use of language in workplace domain, use of language in religion domain, and practice traditional ceremony. The dominant factors affect the maintain the maintain of Bahasa Angkola was living together and see each other frequently. In other hand, some of the factors that found of this research are not in line with the theory of Holmes of the cultures and customs difference of the Angkola Speakers at Langgar Community in Kota Medan.
\end{abstract}

Keywords- Language Maintenance, Bahasa Angkola, Langgar Community.

\section{INTRODUCTION}

Language is a cultural identity. Language and identity are inextricably linked each other and in order to save identity, language users must attempt to save their language. Similarly, the use of language is one way that is used to establish our identity and shaping of other people's views of who we are [1]. Thus, language plays an important role in defining who we are, and makes us instantly recognizable to other members of our particular speech community.

In Indonesia, there are hundreds of ethnic languages that consist of five big islands and hundreds of small islands. Each island has some ethnic groups which are create of many languages. Each of these languages is unique. Based on the data of UNESCO in the year of 2001, there are 6.900 languages in the world, and 2.500 of them are extinction. UNESCO said that Indonesia is facing a very big danger of language shift. Based on the data of UNESCO, almost 200 languages do not exist any longer after three generations, because they lost their native speakers. Similarly, as it was informed by [2] about 736 of 746 vernaculars in Indonesia are endangered. She also explained that generally the numbers of the vernacular languages' speakers tend to be less caused of there is no writing form of the language. Thus, the oral tradition that developed in minority languages if not immediately documented it will be difficult to maintain their existence.

This study was analyzed the factors of maintaining Bahasa Angkola at Langgar Community in Kota Medan. The finding of this research deals with the resnacular language eventhough they do not live in a dominant area of their tribe. This study shows how the vernacular language are maintained by the speakers in a dominant area of the other language.

\section{THEORETICAL BASIS}

\section{A. Language Maintenance}

In describing the term maintenance [3] notes that language maintenance is not merely the absence of language shift. The term is used to refer to the situation where a speech community continues to use its traditional language in the face of a host of conditions that might foster a shift to another language. [4] also states that language maintenance is an effort in keeping the language alive by using the language continually in facing the competition among other languages in society. It means that the existence of the language depend on the effort of the speakers in maintaining that language by using that language continually. Moreover, language maintenance describes use and indigenous language continuously in all language contexts. The process of language maintenance refers to the retention of language and its transmission over several generations.

[5] make the distinction that language maintenance relates to the continuing use and proficiency in a language concerning both groups and individuals, in the face of competition from another language. Language maintenance is the protection and promotion of the first or native language in an individual or within a speech community, particularly among language minorities. Yet languages have no existence without people, the process of language maintenance involves different levels, 
individuals, community, nation, and linguists [6]. It means that language maintenance is an effort to protect the first language in speech community by the speakers of its language.

Furthermore, Language maintenance refers to if the minority language is retained by its traditional speech community without the intervention of language planning activities [7]. It describes the situation where speech community retains the use of their languages without intervention of language planning despite competition from the locally and globally dominant languages. Language maintenance described as three generation process. The first generations still use vernacular language at home though they know another language (Indonesian language), the second generation use vernacular language at home but shift towards Indonesian language at school and in the work place and the third generation, the vernacular language disappears totally.

It can be concluded that language maintenance is an effort which done by minority group to keep the existences of the vernacular in a multicultural society that have different culture diversity and ethnic identity. Beside that, language maintenance also refers to the minority group which successful in keeping their original language in spite of the pressure exhorted on it by a dominant linguistic group. Thus, the successful in keeping the existence of Angkola language is interested to conduct.

\section{B. Factors Affecting Language Maintenance}

Language maintenance refers to a situation where the minority group successful in keeping their original language in spite of the pressure exhorted on it by a dominant linguistic group. Despite, multilingual effects to the local language, it is the main problem which takes over the certain language use domain. However, language maintenance process in a community or group of speech possibly happen if people in that community are willing to use that language. Positive attitude toward mother language is one of determinant factors in maintenance process of a language.

The most decisive factor in the future of the endangered language is the will and the attitude of the speech communities. Without the interest of the speech community in revitalization, any effort to promote institutional protection would be senseless and insignificant [8]. It seems only the speakers of the minority languagecan say wether the maintenance of their language is important.

Therefore, [9] states briefly that there are some other factors that can maintain a language, they are:

1) environment, 2) language attitude, 3) living together and see each other frequently, 4) use of language in family domain (intra marriage and intermarriage), use of language in neighborhood domain, 5) use of language in workplace domain, 6) use of language in religion domain, and 7) practice traditional ceremony.

\section{Bahasa Angkola}

Geographically, North Sumatra is divided into four regions, such as Nias, Southeast Sumatra, Tapanuli, and East Sumatra Regions. Mostly the region in North Sumatra is inhabited by Bataknese people. Bataknese is divided into five main ethnics, they are Batak Toba, Batak Karo, Batak Simalungun, Batak Pakpak-Dairi, and Batak AngkolaMandailing [10]. Every ethnic has their own language, those are: Toba language, Koro language, Simalungun language, Pakpak/Dairi language, and Angkola and Mandailing language.

Batak Angkola is one of the Toba tribe who moved to Sipirok (one of the region in South Tapanuli, the place where Angkola was developed). It is caused by the rapid growing of Batak Toba population that they moved to find out the new place to make their life better. Basically, the spread of Batak Angkola ethnic is wide, but nowadays most of the people know that Angkola is in Padangsidimpuan, Batangtoru, Padanglawas, North Padang Lawas, and South Tapanuli. Angkola and Mandailing language is very similar.

Here are some of the Angkola Language words which are used by Angkolanese people in daily life:

TABLE 1 Angkola Language

\begin{tabular}{|c|c|c|}
\hline $\begin{array}{l}\text { Angkola } \\
\text { Language }\end{array}$ & $\begin{array}{l}\text { Indonesian } \\
\text { Language }\end{array}$ & English \\
\hline$A u$ & Saya & $\mathrm{I}$ \\
\hline $\mathrm{Ho}$ & Кати & You \\
\hline Ayah & Ayah & Father \\
\hline Umak & $I b u$ & Mother \\
\hline Donok & Dekat & Near \\
\hline Juguk & Duduk & Sit \\
\hline Modom & tidur & Sleep \\
\hline Bagas & Rumah & House \\
\hline Ulu & Kepala & Head \\
\hline Ligin & Lihat & look! \\
\hline aha? & apa? & what? \\
\hline sadia? & berapa? & how much? \\
\hline Menek & Kecil & Small \\
\hline Borat & Berat & Heavy \\
\hline Godang & Besar & Big \\
\hline ise goarmu? & siapa namamu? & what is your name? \\
\hline madung & sudah makan? & have you eaten? \\
\hline $\begin{array}{l}\text { mangan? } \\
\text { idia ho sikola? }\end{array}$ & $\begin{array}{l}\text { dimana } \quad \text { kamu } \\
\text { sekolah? }\end{array}$ & $\begin{array}{l}\text { where is your } \\
\text { school? }\end{array}$ \\
\hline nono mataku & aku ngantuk & I'm sleepy \\
\hline $\begin{array}{l}\text { got kehe au tu } \\
\text { kobun }\end{array}$ & $\begin{array}{l}\text { saya mau pergi ke } \\
\text { kebun }\end{array}$ & $\begin{array}{l}\text { I want to go to the } \\
\text { garden }\end{array}$ \\
\hline
\end{tabular}

\section{RESEARCH METHODOLOGY}

This study was conducted by using descriptive qualitative design. [11] description in qualitative design is a description of the characteristics the data accurately in accordance with the nature of the data itself. The data of this study were the utterances of Bahasa Angkola of the Angkolanese speakers at the Langgar Community. The participants were interviewed 
and the result of the interviews were the words, phrase, and sentences relating to the questions identified as the data of this research. The participants of the study were taken by purposive random sampling. Purposive sampling is the technique to determine the sample by certain consideration and it is appropriate to qualitative research [12].

The data were collected by observation, questionnaires, and interview which relate to the factors and strategy which affecting the maintenance of Angkola language. Firstly, The observation were applied to ensure that the participants maintain their language by using the language in their daily life. the researcher went to the site and observe the participants in their daily activity whether they still use Angkola language or not.

\section{ANALYSIS AND DISCUSSION}

The data were analyzed to find the answer of research question about the factors of the Angkolanese speakers maintain the language at Langgar. After collecting the data, the writer found that there are seven factors that affect the Angkola people in maintaining Angkola language at Langgar Community (see appendix 5), they are environment, attitude, using language in family domain (intra marriage and intermarriage), using language in neighborhood domain, using language in religion domain, using language in workplace domain, and practice of Adat Istiadat (Traditional Ceremony). The questionnaire was given to the participants in Langgar Community. Based on the questionnaire that was distributed to 20 participants in Langgar Community (see appendix 1), the interview supports the questionnaire which had been done by the researcher. Based on the questionnaire that were distributed to the participants wich related to the factors that affecting the language maintainance at Langgar Community, ethno linguistic vitality and living together and see each other frequently seems to have a big role to Angkola language maintenance by the Angkola people.

\section{1) Environment Factor}

Living in area that dominated by Angkola people is one of the factors that supported the Angkola people still maintained their language. Angkola people maintained their language by using the language while they communicate each other although sometimes they use Bahasa Indonesia because the environments also inhabited by the other ethnics. It could be seen from the utterances from the participant below;

AR : Olo inang, arana lek gokan alak Angkola dison makana lek tarbiaso marbahasa Angkola. (Yes, because Angkolanese is the most population here, So I am used to speak Angkola here.) (Table 1 U1)

Based on the statement from the participant, it can be concluded that Langgar was dominated by the Angkolanese people which make the environment there closely like an Angkolanes area where we can hear Angkola language. However, the other population also inhabited by Mandailingnese people which is known their language is similar wioth Angkola Language so they can interact each other with their own language.

\section{2) Language attitude}

Based on the data from questionnaire all the participants are proud being and used Angkola language. It can be seen from some participants' statements (see appendix 5) as follow; AR : Bangga tong inang, memang alak Angkola do iba bope lahir di Medan. (I'm so proud, I'm definitely Angkola tribe eventhough I was born in Medan. (Table 2 U1)

The entire participants asserted that they are proud using Angkola language. Moreover, all of them wanted Angkola language or the other language will be taught in school to introduce the various ethnics in Indonesia.

4) Use of language in family domain (intra marriage and intermarriage)

Based on the data from questionnaire, there are 15 participants of intra marriage family speak Angkola language at home, 4 family from intermarriage do not speak Angkola language and 1 family from intra marriage family speak Angkola language at home.

It could be seen from the data (appendix 5, table 3);

AR : Kadang bahasa Angkola, kadang marbahasa Indonesia harana halai jot jotan Bahasa Indonesia alai aben na mulai menek disikola nialai marbahasa Indonesia, jadi dongan ni alai pe gokan halak Medan asli. (Sometimes I use Angkola language and Indonesian because they (children) often use Indonesian language since they were kids they used Indonesian in their school and most of their friends use Indonesian language.) (Table 3 U1)

\section{4) Use of language in neighborhood domain}

Based on the data from questionnaire showed that there are 15 participants used Angkola language to their neighbor or friends. It showed that some of the participants always speak Angkola language with their neighbor or friends.

Meanwhile, some of participants asserted that various answer when they are asked the languge with their neighbours, it could be seen from appendix 5;

NHS : :Marcampur ma inang...abenna gokan halak Angkola dison rap Mandailing jadi marbahasa ita ma jot jotan..Cuma adong juo tetangga i na alak jawa jadi marbahasa Indonesia..i pe da mangarti do ia saotik saotik bahasa ita aben na jot jot $i$ di bege ia raku. (most of people here are Angkolanese and Mandailingnese so we often use that language but there are others ethnic so we use Indonesian language eventhough they also understand a bit of Angkola language because they often hear it here) (Table 4 U 18)

5) Use of language in workplace domain

Workplace is people daily activities that there should be happen interaction among the workers. Data from 
questionnaire showed that 17 from 20 participants use both of Angkola and Indonesian language and 3 participants used Indonesian language when they are in workplace domain. Most of the Angkolanese people are sellers so it makes them have the chance to speak Angkola language because they interact with many buyers from various ethnics. As the participant statements when they are asked what language that they used in workplace domain (see appendix 5 table 6) below;

SH :Marbahasa Indonesia, harana gokan dongan karejo marbahasa Indonesia do, Cuma adong juo dongan na bisa marbahasa Mandailing jadi bisa ma kadang marbahasa Angkola anggo rap ia.

(Indonesian language, because most of my workmates use Indonesian language, but there are some who come from the same tribe like me we we often speak Angkola at office) (Table 6 U2)

6) Use of language in religion domain

The data showed that Angkola people used Angkola language in religion domain. They spoke Angkola language when they were in mosque. As some of participants commented below (see appendix 5);

KH : Dohot anggi, disi pe arana gokan anggota na alak Mandailing rap Angkola makana mabahasa daerah. (I follow the Wirit Activity here, because most of Angkolanese people there so we use Angkola language) (Table 5 U5)

7) Practice traditional ceremony

Practice traditional ceremony is one the factor affecting the maintenance of Angkola language. There are many kinds of traditional ceremony such as upah-upah, ceremony, wedding ceremony, makhobar ceremony, and etc. In the traditional ceremony, the Angkola people use and speak Angkola language because it is the element of their culture. Angkola people said that the practice of traditional ceremony is the factor that affecting Angkola language maintainance. The Angkola people who follow the traditional ceremony speak Angkola language among them. In the traditional ceremony such as makhobar ceremony, usually pemuka adat (hatobangon) used Angkola language when they gave the advices for the marriage couple. By following this activity, they can keep the existence of their culture

\section{CONCLUSIONS}

In accordance with the data, discussion and finding of Factors affecting Angkola maintenance at Langgar community in Kota Medan are; Environment, language attitude, living together and see each other frequently, use of language in family domain, use of language neighborhood domain, use of language in workplace domain, use of language in religion domain, and practice of Adat Istiadat. The dominant factor is the living together and see each other frequently. It means that living in area dominated by Angkolanese people support the Angkolanese people to speak Angkola language in their surrounding at Langgar community.

\section{References}

[1] Thomas, L. Singh, I. \& Peccei, J. S. Language, Society and Power: An Introduction. London: Routledge. 2004.

[2] Multamia. Bahasa Daerah yang Terancam Punah. Retrieved from http://nasional.kompas.com/read/2008/08/11/21544654/169.bahasa.daer ah.terancam.punah accessed on 4/10/2017. 2008.

[3] De Vries, J. Language maintenance and shift: Problems of measurementIn W. Fase, K. Jaspaert \& S. Kroon (Eds.) .Maintenance and Loss of Minority Languages (pp.25-34). Amsterdam, Philadelphia: John Benjamins. 1992.

[4] Fishman, J.A. Can Threatened Languages Be Saved? Sydney: Matters. 2000.

[5] Fase, W, Jaspaert, K. \& Kroon, S. Maintenance and loss of minority languages. Amsterdam: John Benjamins Publishing Company. 1992.

[6] Baker C., Foundations of Bilingual Education and Bilingualism. 5th ed. A.1.: Multilingual Matters. 2011.

[7] Hyltenstam, C. and Stroud, C. Language Maintenance. In Contact Linguistics, Goebl et al. (eds0, 567-578. Berlin: Walter de Gruyter. 1996.

[8] Sanchez-Castro, O. \& Gil, J., Two perspective on language maintenance: The salvadorian communityin Queensland and the Spanish community in South Australia. International Journal of Language Society and Culture, 6 (3-5), pp. 36-47. 2009.

[9] Holmes, J. An Introduction to Sociolinguistcs. Essex: Pearson Education. 2001.

[10] Siahaan, Nalom. Sejarah Kebudayaan Batak. Medan: Napitupulu Publisher. 2006.

[11] Sugyono. Metode Penelitian Pendidikan. Alfabeta. Bandung. 2008.

[12] Bogdan, R \& Biklen, S. Qualitative Research for education $\left(2^{\text {nd }}\right.$ ed).Boston:Allan \& Bacon. 1982. 